\title{
Calcium influence on phosphorus regulation in Daphnia magna: implications for phosphorus cycling
}

\author{
Qiao-Guo Tan, Wen-Xiong Wang* \\ Department of Biology, The Hong Kong University of Science and Technology (HKUST), Clear Water Bay, Kowloon, \\ Hong Kong SAR
}

\begin{abstract}
We examined the influence of environmental calcium on phosphorus biokinetics and regulation in Daphnia magna. When the Ca concentration in culturing media increased from 0.5 to $200 \mathrm{mg} \mathrm{l}^{-1}$, the specific P content of $D$. magna feeding on P-sufficient algae decreased significantly from 1.43 to $1.05 \%$ of dry weight. There was a significant negative relationship between the specific $\mathrm{Ca}$ and $\mathrm{P}$ contents (\% dry wt) of daphnids. However, measured biokinetic parameters, including the assimilation efficiency (AE) of dietary $\mathrm{P}$, the weight-specific ingestion rate (IR), the uptake of inorganic $\mathrm{P}$ from water, and the efflux rate constant $\left(k_{e}\right)$ of $P$, were similar over the wide range of Ca concentrations, with some exceptions at the lowest Ca level $\left(0.5 \mathrm{mg} \mathrm{l}^{-1}\right)$. Diet was the dominant source of $\mathrm{P}$ for daphnids, and only 1 to $2 \%$ of $\mathrm{P}$ was incorporated from water, based on the biokinetic calculation. With the elevation of the Ca level from 0.5 to $200 \mathrm{mg}$ $\mathrm{l}^{-1}$, the proportion of $\mathrm{P}$ lost through molting by $D$. magna feeding on P-sufficient diets increased 2.5 -fold, whereas the dissolved release decreased 1.9 -fold. P released into the dissolved phase is readily re-utilized by primary producers, while P contained within the shed molts sinks out of the epilimnion and becomes at least temporarily unavailable to primary producers; thus, the effects of $\mathrm{Ca}$ on molting and dissolved release have significant implications for $\mathrm{P}$ cycling in freshwater lakes. Our results suggest that the availability of $\mathrm{P}$ to primary producers can be reduced by sedimentation of P-rich daphnid molts in high-Ca lakes, and $\mathrm{Ca}$ concentration in the water needs to be considered in studying the stoichiometric regulation of $\mathrm{P}$ in freshwater cladocerans.
\end{abstract}

KEY WORDS: Phosphorus regulation - Phosphorus cycling · Phosphorus biokinetics - Effects of calcium · Daphnia magna

Resale or republication not permitted without written consent of the publisher

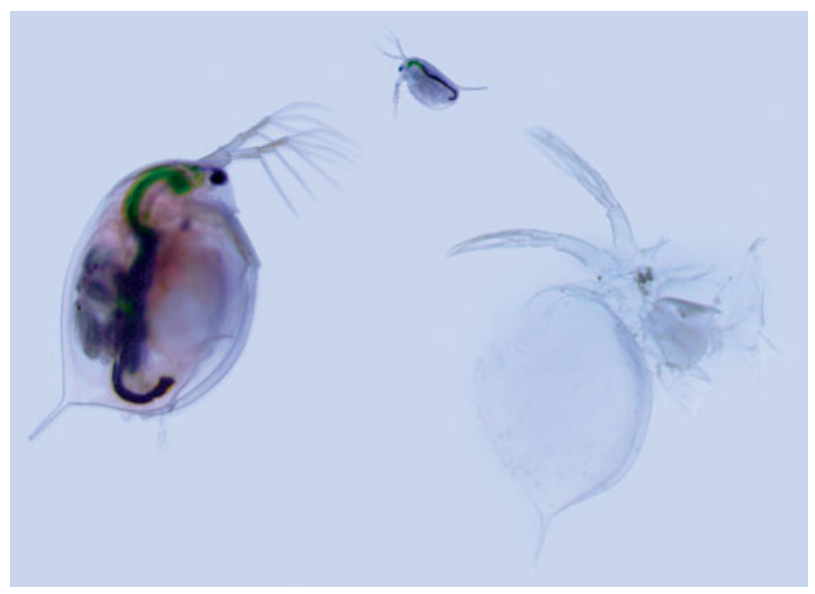

The relative importance of different routes of phosphorus loss from Daphnia magna (via excretion, reproduction and molting) is affected by the calcium level in the water.

Photo: Ke Pan

\section{INTRODUCTION}

Like all crustaceans, Daphnia spp. shed and re-build their exoskeleton periodically as they grow, leading to a substantial drain of, and demand for, a number of elements. Calcium and phosphorus have attracted much attention (Peters \& Rigler 1973, Alstad et al. 1999, Hessen \& Rukke 2000, He \& Wang 2007) due to their high content in the exoskeleton and high requirement by Daphnia. Most Ca in Daphnia is bound within the carapace and $~ 90 \%$ of Ca in Daphnia magna is lost during 1 molting event (Alstad et al. 1999). Although the major pool of $\mathrm{P}$ in $D$. magna and $D$. galeata is nucleic acids and phospholipids contained in the soft tissues, Vrede et al. (1999) found that more than $14 \%$ 
of $\mathrm{P}$ is distributed within the carapace, possibly bound with Ca. Sterner et al. (1993) found that D. obtusa on a P-deficient diet has problems in molting. Shedding molts accounts for $\sim 70$ and $\sim 50 \%$ of P loss from juvenile and adult $D$. magna over a 3 to $4 \mathrm{~d}$ period, respectively (He \& Wang 2007). The link between $\mathrm{Ca}$ and $\mathrm{P}$ in D. magna is also indicated by the crystalline calcium phosphate composition of the shell of its ephippia (Kawasaki et al. 2004). Ca levels in the water considerably affect the calcification of the carapace of daphnids (Alstad et al. 1999) and, thus, their total Ca content (Jeziorski \& Yan 2006, Tan \& Wang 2008). It is therefore tempting to ask whether the content and distribution of $\mathrm{P}$ in daphnids is also affected by the aqueous Ca level, considering the close association of these 2 elements in these organisms.

Among the various freshwater zooplankton species, Daphnia spp. are at the high end in terms of both $\mathrm{Ca}$ and P contents (Andersen \& Hessen 1991, Hessen \& Lyche 1991, Wærvågen et al. 2002, Jeziorski \& Yan 2006). The high $\mathrm{Ca}$ and $\mathrm{P}$ contents suggest high demand, which may render daphnids more susceptible to a limitation of $\mathrm{Ca}$ and $\mathrm{P}$ availability. Compared with the broad variation in Ca content in Daphnia spp. (from $<2$ to $>10 \%$ dry wt; Hessen et al. 2000), the variation in $\mathrm{P}$ content is relatively restricted, with most observations lying within the range of 1.1 to $1.7 \%$ of dry wt (Hessen 1990). Ca content in daphnids is mainly dependent on the aqueous $\mathrm{Ca}$ level because water is the dominant source of Ca for daphnids (Tan \& Wang 2009). In contrast, $P$ is mainly assimilated from food, and daphnids can be cultured in a P-free medium (Ferrão-Filho et al. 2007). Therefore, the $\mathrm{P}$ content in daphnids is substantially influenced by the C:P ratio in their food, and was found to drop from 1.66 to $0.99 \%$ when the atomic C:P ratio of food increased from 140 to 615 (DeMott et al. 2004). Daphnids are also able to incorporate inorganic P from water (Rigler 1961, Urabe et al. 1997); however, the importance of such supplementation has not yet been quantitatively studied.

As one of the major components of freshwater zooplankton, daphnids play an important role in the cycling of $\mathrm{P}$ in lake ecosystems through grazing on phytoplankton and regenerating $\mathrm{P}$ (Andersson et al. 1988). Unassimilated $P$ is egested into the water in the form of fragile fecal pellets and then quickly becomes dissolved and readily available to phytoplankton (Andersson et al. 1988). P assimilated into daphnids is lost mainly in 3 ways (He \& Wang 2007, 2008): (1) excretion into the dissolved phase (released P is directly usable for primary producers); (2) shedding molts, which may sink out of the epilimnion ( $\mathrm{P}$ becomes temporarily unavailable to primary producers); (3) reproduction, leading to the growth of the daphnid population (suggested to be more important than molt- ing as a P drain for phytoplankton; Sommer et al. 2003). Any substantial change to the relative importance of the 3 routes of $\mathrm{P}$ loss may affect the $\mathrm{P}$ cycle. Therefore, it is meaningful to examine whether $\mathrm{Ca}$ can affect $\mathrm{P}$ cycling through its effects on the molting of daphnids.

The aim of this study was to investigate the effects of aqueous $\mathrm{Ca}$ levels on the $\mathrm{P}$ content and regulation in daphnids and on the role of daphnids in P cycling. Daphnia magna is typically found in freshwaters with Ca concentrations ranging from 5 to $280 \mathrm{mg} \mathrm{l}^{-1}$ (Fryer 1985). In addition, the ecological niche of Ca concentration for D. magna can be as low as $0.5 \mathrm{mg} \mathrm{l}^{-1}$ (Hooper et al. 2008). Therefore, in the present study we used Ca concentrations ranging from 0.5 to $200 \mathrm{mg} \mathrm{l}^{-1}$. By using the radiotracer ${ }^{33} \mathrm{P}$ and a well-established biokinetic model (Wang et al. 1996, Guan \& Wang 2006), it was possible to quantify the effects of aqueous $\mathrm{Ca}$ levels on the influx and efflux of $\mathrm{P}$, and on the relative importance of the 3 efflux routes of $\mathrm{P}$. The importance of aqueous inorganic $\mathrm{P}$ as a source of $\mathrm{P}$ for daphnids was also assessed using the biokinetic modeling approach.

\section{MATERIALS AND METHODS}

Organisms, water and radioisotope. The stock Daphnia magna were cultured in GF/C (Whatman) filtered natural freshwater, which was obtained from an unpolluted creek on the campus of the Hong Kong University of Science \& Technology (Kowloon, Hong Kong). The Ca concentration of the creek water was about $20 \mathrm{mg} \mathrm{l}^{-1}$. The quantity of water allocated to each daphnid in culturing was $10 \mathrm{ml}$, and the water was refreshed every second day. The green alga Chlamydomonas reinhardtii was fed daily to the daphnids at a concentration of $10^{5}$ cells $\mathrm{ml}^{-1}\left(2.73 \mathrm{mg} \mathrm{C}^{-1}\right)$; half this concentration was used for age 0 to $3 \mathrm{~d}$ daphnids. The algae were batch-cultured in Woods Hole modified Chu-10 (WC) medium (Guillard \& Lorenzen 1972) with an initial cell density of approximately $10^{4}$ cells $\mathrm{ml}^{-1}$; after 5 to $6 \mathrm{~d}$ of growth with aeration, the cultures reached mid-log phase and were then refrigerated at $4^{\circ} \mathrm{C}$ for less than $10 \mathrm{~d}$ before centrifugation for use. To use the algae as food, the algal suspension was centrifuged at $2830 \times g$ for $10 \mathrm{~min}$ and then resuspended in filtered creek water to a final cell density of approximately $10^{7}$ cells $\mathrm{ml}^{-1}$ (counted using a haemocytometer). The food was kept at $4^{\circ} \mathrm{C}$ and most algal cells remained motile for at least $1 \mathrm{wk}$. The light:dark cycle was $14: 10 \mathrm{~h}$ and the temperature was $23.5^{\circ} \mathrm{C}$ for culturing daphnids and algae and for all the experiments.

To control the Ca concentration in the water, the synthetic fresh water Elendt M7 (Samel et al. 1999) was used instead of creek water in all experiments. 
M7 medium was prepared by adding salts and vitamins to nanopure water (Barnstead): the Ca concentration was adjusted by the addition of $\mathrm{CaCl}_{2} \cdot 2 \mathrm{H}_{2} \mathrm{O}$, and the $\mathrm{pH}$ was adjusted to $8.0 \pm 0.2$ by adding $\mathrm{HCl}$ or $\mathrm{NaOH}$ solutions as necessary. The actual Ca concentrations were measured at the beginning and end of all experiments, and the average values matched well with the nominal concentrations (see Table 1). Because water is the principal source of Ca for Daphnia magna

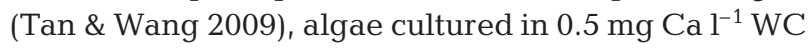
medium were used for all treatments in all experiments in order to avoid any difference in food.

The radioisotope ${ }^{33} \mathrm{P}$ (as $\mathrm{H}_{3} \mathrm{PO}_{3}$ dissolved in water, 5.76 TBq $\mathrm{mg}^{-1}$, half life: $25.3 \mathrm{~d}$, PerkinElmer) was used as a tracer for quantifying the biokinetic parameters.

Phosphorus content of daphnids. Neonates $(<24 \mathrm{~h})$ of the stock daphnids were collected and cultured in M7 medium for $7 \mathrm{~d}$. The specific $\mathrm{Ca}$ and $\mathrm{P}$ contents of the age $7 \mathrm{~d}$ daphnids were measured (described below, under 'Chemical analysis and radioactivity measurement'); 2 independent experiments were conducted for the $\mathrm{P}$ content. The first experiment had no replicates and contained 30 to 50 individuals in each sample. The second experiment had 3 replicates for each $\mathrm{Ca}$ treatment and 10 individuals in each sample.

The $\mathrm{P}$ content was also measured for age $7 \mathrm{~d}$ daphnids cultured in the high Ca medium (200 $\mathrm{mg} \mathrm{l}^{-1}$ ) fed Chlamydomonas reinhardtii of different atomic C:P ratios and different food quantities. Four treatments designated $\mathrm{P}-, \mathrm{P}+, \mathrm{P}++$ and $2 \mathrm{P}+$ represented daphnids fed algae of $C: P=960,93,79$ at normal dose $\left(10^{6}\right.$ cells ind $^{-1} \mathrm{~d}^{-1}$ ) and with doubled dose at $\mathrm{C}: \mathrm{P}=93$, respectively. The C:P ratio gradient was created by using the WC medium of different $\mathrm{P}$ concentrations. The P-sufficient $(\mathrm{C}: \mathrm{P}=93,79)$ algae were cultured (following the method described above) in WC medium containing 50 and $200 \mu \mathrm{M}$ P, respectively; and the P-deficient $(\mathrm{C}: \mathrm{P}=$ 960) algae were cultured by inoculating the P-sufficient algae into the P-free WC medium at a density of approximately $2 \times 10^{4}$ cells ml $\mathrm{ml}^{-1}$ and harvested after 4 to $5 \mathrm{~d}$ of growth.

Biokinetic parameters. With the biokinetic model (Wang et al. 1996, Guan \& Wang 2006), the steadystate concentration $\left(C_{\mathrm{ss}}\right)$ of an element in organisms ( $\mu \mathrm{g} \mathrm{g}^{-1}$ dry wt) is calculated by the following equation:

$$
C_{\mathrm{ss}}=\left(\mathrm{k}_{\mathrm{u}} \times C_{\mathrm{w}}+\mathrm{AE} \times \mathrm{IR} \times C_{\mathrm{f}}\right) /\left(\mathrm{k}_{\mathrm{e}}+g\right)
$$

where $\mathrm{k}_{\mathrm{u}}$ is the dissolved uptake rate constant $\left(\mathrm{l} \mathrm{g}^{-1}\right.$ $\left.\mathrm{d}^{-1}\right), C_{\mathrm{w}}$ is the concentration of the element in water $\left(\mu \mathrm{g} \mathrm{l}^{-1}\right), \mathrm{AE}$ is the assimilation efficiency of the element, IR is the weight-specific ingestion rate $\left(\mathrm{g} \mathrm{g}^{-1} \mathrm{~d}^{-1}\right), C_{\mathrm{f}}$ is the concentration of the element in food $\left(\mu \mathrm{g} \mathrm{g}^{-1}\right), \mathrm{k}_{\mathrm{e}}$ is the efflux rate constant $\left(\mathrm{d}^{-1}\right)$ of the element, and $g$ is the growth rate constant of the organisms $\left(\mathrm{d}^{-1}\right)$. The weight of the organisms (e.g. Daphnia magna) and their foods were expressed on a dry wt basis. The biokinetic parameters $\left(\mathrm{k}_{\mathrm{u}}, \mathrm{AE}, \mathrm{IR}, \mathrm{k}_{\mathrm{e}}\right)$ of $\mathrm{P}$ were thus quantified in age $7 \mathrm{~d} D$. magna cultured at the $4 \mathrm{Ca}$ levels, as described in the following sections.

Dietary assimilation of phosphorus. The AE of $\mathrm{P}$ was quantified in the age $7 \mathrm{~d}$ Daphnia magna using the pulse feeding technique to examine the effects of $\mathrm{Ca}$ levels on the $\mathrm{P}$ AEs. The ${ }^{33} \mathrm{P}$ labeled algae were prepared by adding $1.11 \times 10^{4} \mathrm{kBq} \mathrm{l}^{-1}$ of ${ }^{33} \mathrm{P}$ into the standard WC medium with an initial algal cell density of $2 \times 10^{5}$ cells $\mathrm{ml}^{-1}$. After $3 \mathrm{~d}$ of continuous illumination, the algal cells divided at least twice and thus were considered uniformly labeled with ${ }^{33} \mathrm{P}$. The radioactive algae were twice centrifuged and resuspended in $0.5 \mathrm{mg} \mathrm{Ca}^{-1} \mathrm{M} 7$ medium immediately before the pulse feeding to minimize the amount of weakly adsorbed ${ }^{33} \mathrm{P}$. The $0.5 \mathrm{mg} \mathrm{Ca} \mathrm{l}^{-1} \mathrm{M} 7$ medium was used to reduce the effects of food addition on the Ca concentration of the medium. Three replicates, each containing 35 individuals, were used for each of the 4 treatments. Before the pulse feeding, the daphnids were starved in the water without food addition for 2 to $3 \mathrm{~h}$. Afterwards, the daphnids were fed ${ }^{33} \mathrm{P}$ labeled Chlamydomonas reinhardtii at a concentration of $2.5 \times 10^{4}$ cells ml-1 for $7 \mathrm{~min}$ in the dark, and 5 individuals of each replicate were randomly picked out for radioactivity measurement. Before the radioassay, the daphnids were allowed to swim in a series of 2 beakers containing $200 \mathrm{ml} \mathrm{M7}$ medium of corresponding Ca concentration for 1 to 2 min to minimize the amount of radioisotope adsorbed to the surface of the organisms. The remaining daphnids were depurated in non-radioactive medium containing $5 \times 10^{4}$ cells $\mathrm{ml}^{-1}$ of $C$. reinhardtii for $24 \mathrm{~h}$. The algae were cultured with standard WC medium. Heat-killed algae were used for depuration in order to avoid the recycling of regenerated $\mathrm{P}$ by algae. The algae were heated in $80^{\circ} \mathrm{C}$ water bath for $5 \mathrm{~min}$. Microscopic observations confirmed that the cells were immobilized and the cell morphology was not significantly changed. At 1.5, 3, 5, 7, 12, and 24 h, 5 individuals were picked out for radioactivity measurement, and the water and food were renewed.

Uptake of inorganic phosphorus from water. The effects of $\mathrm{Ca}$ levels in the water on the dissolved uptake of inorganic $\mathrm{P}\left(\mathrm{PO}_{4}-\mathrm{P}\right)$ by Daphnia magna were investigated at the $4 \mathrm{Ca}$ concentrations; 3 replicates of 24 daphnids were used for each treatment. To avoid the uptake of phosphate by bacteria attached to the surface of the daphnids, they were disinfected in foodfree M7 medium of corresponding Ca concentrations for approximately $2 \mathrm{~h}$ by adding 100 units $\mathrm{ml}^{-1}$ of penicillin and $100 \mu \mathrm{g} \mathrm{ml}^{-1}$ of streptomycin (Rigler 1961). During the $2 \mathrm{~h}$, the daphnids evacuated their digestive tracts, such that the generation of feces during the following exposure period was minimized. After that, 
the daphnids were transferred to a ${ }^{33} \mathrm{P}$ labeled $\mathrm{M7}$ medium $\left(370 \mathrm{kBq}^{-1}\right)$ of antibiotics and the corresponding $\mathrm{Ca}$ concentration for a $6 \mathrm{~h}$ exposure. In the exposure medium, the concentration of $\mathrm{PO}_{4}-\mathrm{P}$ was $10 \mu \mathrm{g} \mathrm{l}^{-1}$, and the concentrations of antibiotics were 10 units $\mathrm{ml}^{-1}$ of penicillin and $10 \mu \mathrm{g} \mathrm{ml}^{-1}$ of strepto-

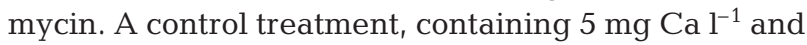
no antibiotics, was used to examine whether the presence of antibiotics affected the uptake of phosphate. At the end of 1, 2, 4 and $6 \mathrm{~h}$ of exposure, 6 daphnids were randomly picked out, rinsed in a series of 3 beakers containing $200 \mathrm{ml}$ of $\mathrm{M} 7$ medium of the corresponding Ca concentrations for approximately $1.5 \mathrm{~min}$ and then radio-assayed. At the beginning and end of the exposure, a $0.5 \mathrm{ml}$ water sample was taken for radioactivity measurement, and the average values were used for calculations. No drop in P concentration was observed, indicating a negligible effect of adsorption to the container and uptake by daphnids.

Efflux and loss budget of phosphorus. The efflux rate constant $\left(\mathrm{k}_{\mathrm{e}}\right)$ and loss budget of $\mathrm{P}$ in age $7 \mathrm{~d}$ Daphnia magna were also quantified at the $4 \mathrm{Ca}$ levels. Newly born $D$. magna $(<24 \mathrm{~h})$ were collected and cultured in M7 medium for $7 \mathrm{~d}$ before the efflux experiment, and the daphnids were labeled with ${ }^{33} \mathrm{P}$ by feeding them with ${ }^{33} \mathrm{P}$-labeled algae during the last $4 \mathrm{~d}$ of this period (long enough to achieve homogeneous labeling; Vrede et al. 1999). The radioactive algae were prepared by culturing Chlamydomonas reinhardtii in $200 \mathrm{ml}$ WC medium (initial cell density $2 \times$ $10^{5}$ cells ml ${ }^{-1}$ ) spiked with $5.18 \times 10^{3} \mathrm{kBq}$ of ${ }^{33} \mathrm{P}$ under continuous light for 2 to $5 \mathrm{~d}$. In each treatment, 180 D. magna individuals were cultured in 1.61 water. On each of the last $4 \mathrm{~d}, 12 \mathrm{ml}$ of the ${ }^{33} \mathrm{P}$-labeled algae were centrifuged and fed to the daphnids together with non-radioactive algae at a total density of $10^{5}$ cells $\mathrm{ml}^{-1}$. The water was replaced on Days 4 and 6. D. magna labeled with ${ }^{33} \mathrm{P}$ were depurated in corresponding non-radioactive M7 medium for $3 \mathrm{~d}$, during which the water samples, the produced molts and neonates were collected for quantifying the loss of ${ }^{33} \mathrm{P}$ from daphnids into the environment.

The daphnids were evacuated in corresponding M7 medium without the addition of food for $2 \mathrm{~h}$ before the depuration in order to minimize the ${ }^{33} \mathrm{P}$ associated with feces in the gut. In each treatment, 30 ind. were then randomly taken for measuring the radioactivity, which was considered the initial ${ }^{33} \mathrm{P}$ content in daphnids; 90 ind. were equally divided into 3 replicates for the efflux experiment and the remaining daphnids were collected for dry wt measurement. In order to ensure high enough radioactivity in the water during the depuration period, the volume of water for each daphnid was reduced to $6 \mathrm{ml}$. Heat-killed Chlamydomonas reinhardtii was fed as food during the depuration period to avoid the recycling of ${ }^{33} \mathrm{P}$ by algae, and the food density was $10^{5}$ cells $\mathrm{ml}^{-1}$. Every $0.5 \mathrm{~d}$, the medium and food were renewed and the produced molts and neonates and $5 \mathrm{ml}$ of medium were collected for radioactivity assay. Before taking the water samples, $1 \mathrm{ml}$ of $\mathrm{KH}_{2} \mathrm{PO}_{4}$ solution $\left(18 \mathrm{~g} \mathrm{P} \mathrm{l}^{-1}\right)$ was added to the $180 \mathrm{ml}$ medium to reduce the possible absorption of ${ }^{33} \mathrm{P}$ onto the wall of plastic beakers. At the end of depuration, the daphnids were collected for radioactivity measurement. The amount of ${ }^{33} \mathrm{P}$ retained in daphnids at each time point was calculated by deducting the ${ }^{33} \mathrm{P}$ in medium, molts and neonates from the initial ${ }^{33} \mathrm{P}$ content in daphnids. The recovery of ${ }^{33} \mathrm{P}$ was calculated with the following equation:

$$
\text { Recovery }(\%)=A_{\mathrm{w}+\mathrm{m}+\mathrm{n}} /\left(A_{0}-A_{\mathrm{t}}\right) \times 100 \%
$$

where $A_{\mathrm{w}+\mathrm{m}+\mathrm{n}}$ is the ${ }^{33} \mathrm{P}$ in water (counts per min, CPM), molts and neonates, $A_{0}$ is the ${ }^{33} \mathrm{P}$ in daphnids at the beginning of depuration (CPM) and $A_{\mathrm{t}}$ is the ${ }^{33} \mathrm{P}$ in daphnids at the end of depuration (CPM). The recovery for the $0.5,5,50$ and $200 \mathrm{mg} \mathrm{Ca} \mathrm{l}^{-1}$ treatments was $85.3 \pm 0.9,88.3 \pm 0.8,95.4 \pm 3.9$ and $86.0 \pm 1.4 \%$, respectively (mean $\pm \mathrm{SD}_{\mathrm{i}} \mathrm{n}=3$ ). The data of ${ }^{33} \mathrm{P}$ retained in daphnids were corrected against the recovery and the decay of ${ }^{33} \mathrm{P}$.

Chemical analysis and radioactivity measurement. Ca concentration was measured using flame atomic absorption spectrometry (AAS) (PerkinElmer AAnalyst 800). The daphnids were first evacuated for ca. $2 \mathrm{~h}$. For each sample, 15 to 20 ind. were collected by filtering onto $1 \mu \mathrm{m}$ polycarbonate membranes, then rinsed 3 times with $10 \mathrm{ml}$ nanopure water, dried overnight at $80^{\circ} \mathrm{C}$, and the dry wt was measured to the nearest $10 \mu \mathrm{g}$. The daphnids were then ashed in a muffle furnace at $500^{\circ} \mathrm{C}$ for $2 \mathrm{~h}$, and dissolved in $10 \mathrm{ml}$ of $2 \%$ $\mathrm{HNO}_{3}$. To measure the specific Ca content of Chlamydomonas reinhardtii, the algae suspension was concentrated by centrifugation, and $1 \mathrm{ml}$ of the concentrated algal suspension was filtered onto a pre-weighed $1 \mu \mathrm{m}$ polycarbonate membrane, dried overnight at $80^{\circ} \mathrm{C}$ and the dry weight was measured to the nearest $10 \mu \mathrm{g}$. Another $10 \mathrm{ml}$ of the suspension was centrifuged and resuspended with $0.9 \% \mathrm{NaCl}$ solution twice to minimize the effect of $\mathrm{Ca}$ in water on the measurement, and then centrifuged. The algal pellets were digested using $2 \mathrm{ml}$ of $30 \% \mathrm{HNO}_{3}$ for $1 \mathrm{~d}$ at $85^{\circ} \mathrm{C}$. The daphnid and alga samples were diluted to the range of 0.4 to $4 \mathrm{mg} \mathrm{Ca} \mathrm{l}^{-1}$. Lanthanum chloride was added into the samples to reduce interference from $\mathrm{Al}, \mathrm{Si}, \mathrm{PO}_{4}{ }^{3-}$, and $\mathrm{SO}_{4}{ }^{2-}$. The final samples contained $2 \% \mathrm{HNO}_{3}$ and $1 \%$ lanthanum.

The P content of Daphnia magna and Chlamydomonas reinhardtii was measured using the methods described in Solorzano \& Sharp (1980). Briefly, daphnids were collected, dried and weighed as mentioned 
above; algae were collected by filtering $1 \mathrm{ml}$ of the suspension onto a GF/F filter (Whatman). Both the daphnids and algae were washed with $2 \mathrm{ml}$ of $0.17 \mathrm{M}$ $\mathrm{Na}_{2} \mathrm{SO}_{4}$ twice, placed in a $14 \mathrm{ml}$ glass scintillation bottle and $2 \mathrm{ml}$ of $0.017 \mathrm{M} \mathrm{MgSO}_{4}$ was added. The samples were dried at $95^{\circ} \mathrm{C}$ and ashed at $500^{\circ} \mathrm{C}$ for $2 \mathrm{~h}$, and dissolved in $10 \mathrm{ml}$ of $0.2 \mathrm{M} \mathrm{HCl}$ after cooling. The bottles were tightly capped and heated at $80^{\circ} \mathrm{C}$ for $30 \mathrm{~min}$. The samples were diluted to a range of 0.4 to $4 \mu \mathrm{M}$ $\mathrm{P}$ and measured using the molybdenum blue spectrophotometric method.

The ${ }^{33} \mathrm{P}$ radioactivity in the samples was measured using a Beckman LS-6500 Liquid Scintillation Counter (Fullerton). The samples were counted for $3 \mathrm{~min}$ or longer if necessary to ensure propagated counting errors of less than $5 \%$. The daphnid and molt samples were prepared by digesting them with $0.5 \mathrm{ml} 30 \%$ $\mathrm{HNO}_{3}$ at $80^{\circ} \mathrm{C}$ for $6 \mathrm{~h}$ in a $7 \mathrm{ml}$ scintillation vial. Thereafter, $5 \mathrm{ml}$ of scintillation cocktail (PerkinElmer) was added and the mixtures were well mixed by mechanical shaking. After $8 \mathrm{~h}$ of equilibration, the radioactivity was measured using the scintillation counter. Water samples were mixed with scintillation cocktail directly and measured following the same method. The acid quenching effect was quantified and used for correction of the data.

\section{RESULTS}

\section{Ca and $P$ contents of algae and daphnids}

The specific Ca content of the algae ranged from 1.25 to $3.95 \mathrm{mg} \mathrm{g}^{-1}$ when the ambient Ca concentration varied from 0.5 to $200 \mathrm{mg} \mathrm{l}^{-1}$ (Table 1). Generally, algae cultured in the low Ca medium $\left(0.5 \mathrm{mg} \mathrm{l}^{-1}\right)$ had lower $\mathrm{Ca}$ content. When the ambient Ca concentration was above $5 \mathrm{mg} \mathrm{l}^{-1}$, Ca content in algae was similar among treatments. The specific P content of algae was not significantly affected by $\mathrm{Ca}$ concentration in the medium ( $p>0.05,1$-way ANOVA) and ranged from 9.33 to $14.90 \mathrm{mg} \mathrm{g}^{-1}$ when ambient Ca concentration varied from 0.5 to $200 \mathrm{mg} \mathrm{l}^{-1}$ (Table 1 ).

The specific Ca content in daphnids increased continuously from 2.17 to $4.98 \%$ of dry wt when the ambient Ca concentration increased from 0.5 to $200 \mathrm{mg} \mathrm{l}^{-1}$ (Table 1). The $\mathrm{P}$ content varied less than the Ca content, and decreased significantly from 1.43 to $1.05 \%$ of dry wt when the ambient $\mathrm{Ca}$ concentration increased from 0.5 to $200 \mathrm{mg} \mathrm{l}^{-1}$ (Table 1). A negative relationship $\left(\mathrm{r}^{2}=0.987\right)$ was observed between the P content and the Ca content of daphnids (Fig. 1).

Daphnids fed P-deficient food (atomic C:P = 960) had lower P content $(0.72 \%)$ compared with daphnids fed P-sufficient food ( $\mathrm{C}: \mathrm{P}=79$ to 93). Increases in the food

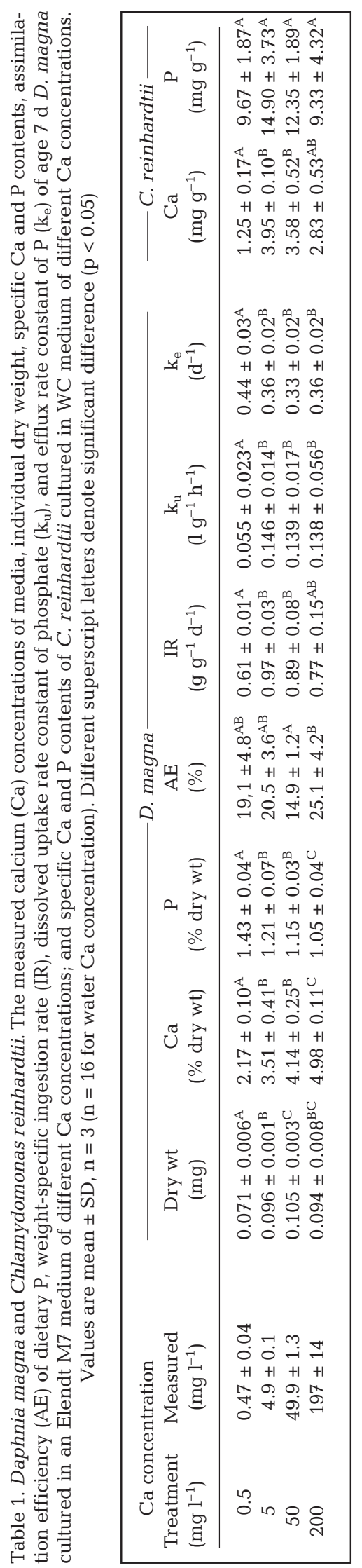




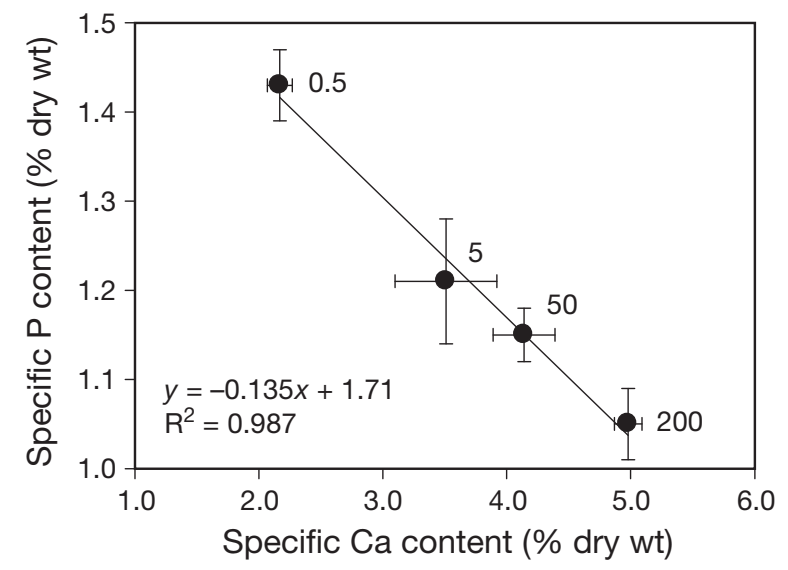

Fig. 1. Daphnia magna. Relationship between specific phosphorus (P) content and specific calcium (Ca) content of age $7 \mathrm{~d}$ D. magna cultured in different Ca concentrations $\left(\mathrm{mg} \mathrm{l}^{-1}\right.$, indicated next to the dots). Error bars: \pm SD, $n=3$

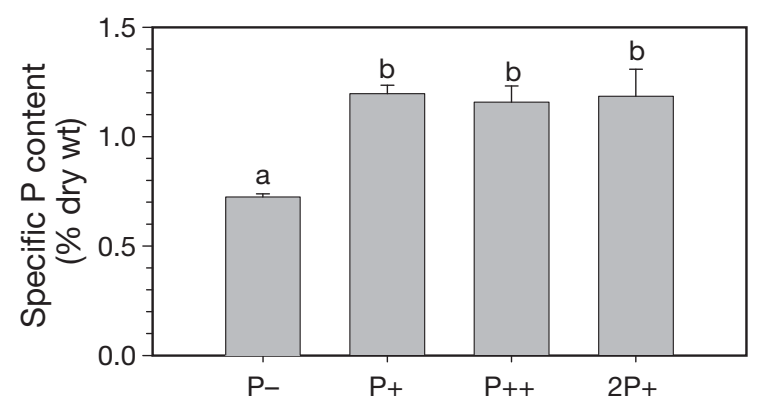

Fig. 2. Daphnia magna. Specific phosphorus content of age $7 \mathrm{~d}$ D. magna cultured in $200 \mathrm{mg} \mathrm{Ca}^{-1}$ and fed Chlamydomonas reinhardtii. Error bars: $+\mathrm{SD}, \mathrm{n}=3$. Different letters above the bars denote significant differences $(\mathrm{p}<0.05)$. P-: P-deficient algae (atomic C:P = 960); $\mathrm{P}+$ : $\mathrm{P}$-sufficient algae (atomic $\mathrm{C}: \mathrm{P}=$ 93); P++: P-sufficient algae with elevated P-content (atomic $\mathrm{C}: \mathrm{P}=79) ; 2 \mathrm{P}+\mathrm{P}$-sufficient algae $(\mathrm{P}+)$ of doubled quantity

quantity and further increases in the food $\mathrm{P}$ content did not significantly elevate the $\mathrm{P}$ content of daphnids when they were fed the P-sufficient food $(\mathrm{C}: \mathrm{P}=93)$ (Fig. 2).

\section{Dietary assimilation and dissolved uptake of phosphorus}

The unassimilated $\mathrm{P}$ was rapidly lost by the daphnids during the first 1 to $3 \mathrm{~h}$, and the percentage of retained $\mathrm{P}$ was almost stable during the following $21 \mathrm{~h}$ of depuration (Fig. 3A). The AEs were thus calculated using the intercept method (He \& Wang 2007) using the data of $3 \mathrm{~h}$ onwards. Linear regressions were determined between the natural log of the percentage of $\mathrm{P}$ retained and the time of depuration, and the intercept of the regression was considered as the $\mathrm{AE}$ (Table 1). The
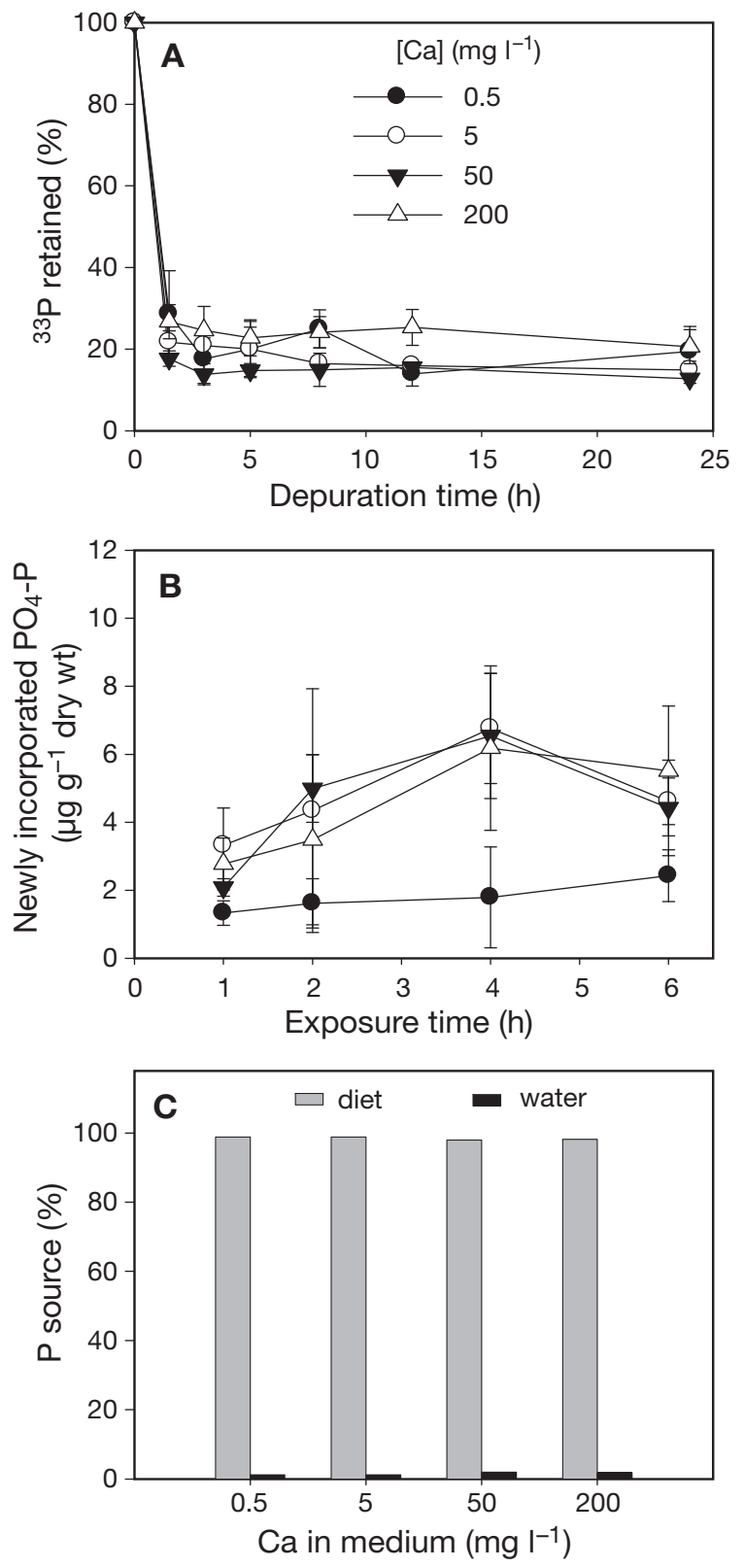

Fig. 3. Daphnia magna. (A) Percentage of ${ }^{33} \mathrm{P}$ retained in age $7 \mathrm{~d} D$. magna during the $24 \mathrm{~h}$ depuration; ${ }^{33} \mathrm{P}$ was ingested during a $7 \mathrm{~min}$ pulse feeding on labeled Chlamydomonas reinhardtii. (B) Uptake of $\mathrm{PO}_{4}-\mathrm{P}$ during $6 \mathrm{~h}$ exposure to $10 \mu \mathrm{g}$ $\mathrm{l}^{-1} \mathrm{PO}_{4}$-P and antibiotics. (C) Relative importance of food and water as the source of $\mathrm{P}$ for $D$. magna calculated from the biokinetic model. Error bars: $\pm \mathrm{SD}, \mathrm{n}=3$

AEs of $\mathrm{P}$ were not significantly affected by the Ca level ( $p>0.05$, 1-way ANOVA), and ranged between 14.9 and $25.1 \%$. IR was also calculated using the data of 7 min pulse feeding and listed in Table 1. Ca concentration in the environment had no significant effect on IR ( $p>0.05,1$-way ANOVA), and when the food concentration was $2.5 \times 10^{4}$ cells $\mathrm{ml}^{-1}$, IRs were in the range of 0.61 to $0.97 \mathrm{~g} \mathrm{~g}^{-1} \mathrm{~d}^{-1}$. 
The $6 \mathrm{~h}$ dissolved uptake of inorganic phosphorus did not follow a linear pattern (Fig. 3B), thus it is difficult to calculate the unidirectional influx rate or dissolved uptake rate constant $\left(\mathrm{k}_{\mathrm{u}}\right)$ based on the linear regression method ( $\mathrm{Yu} \&$ Wang 2002). The dry wt concentration factor (DCF, $\mathrm{l} \mathrm{g}^{-1}$ ) of newly incorporated $\mathrm{P}$ during the dissolved uptake was calculated as:

$$
\mathrm{DCF}=A /\left(A_{\mathrm{w}} \times 1000\right)
$$

where $A$ is the radioactivity in the daphnids $\left(\mathrm{CPM} \mathrm{g}^{-1}\right)$, $A_{\mathrm{w}}$ is the radioactivity in the water $\left(\mathrm{CPM} \mathrm{ml} \mathrm{m}^{-1}\right)$. The dissolved uptake rate constants $\left(\mathrm{k}_{\mathrm{u}}, \mathrm{l} \mathrm{g}^{-1} \mathrm{~h}^{-1}\right)$ of $\mathrm{P}$ were estimated with the following equation and are shown in Table 1:

$$
\mathrm{k}_{\mathrm{u}}=\Sigma \mathrm{DCF}_{i} / \Sigma t_{i}
$$

where $\mathrm{DCF}_{i}$ is the dry weight concentration factor of $\mathrm{P}$ at time $t_{i}\left(\mathrm{l} \mathrm{g}^{-1}\right)$ and $t_{i}$ is the time of exposure (h).

The calculated $\mathrm{k}_{\mathrm{u}}$ in the control treatment (5 mg Ca $\mathrm{l}^{-1}$, no antibiotics added during exposure) was $0.182 \pm$ $0.033 \mathrm{l} \mathrm{g}^{-1} \mathrm{~h}^{-1}$, which was not significantly different from the $5 \mathrm{mg} \mathrm{Ca}^{-1}$ treatment with antibiotics added ( $p>0.05, t$-test). Thus, the presence of antibiotics did not significantly affect the dissolved uptake of P. The dissolved uptake of $\mathrm{P}$ was significantly lower in the $0.5 \mathrm{mg} \mathrm{l}^{-1}$ treatment $\left(0.055 \mathrm{l} \mathrm{g}^{-1} \mathrm{~h}^{-1}\right)$, while it was similar among the other treatments $\left(0.138\right.$ to $\left.0.146 \mathrm{l} \mathrm{g}^{-1} \mathrm{~h}^{-1}\right)$.

Based on the $\mathrm{AE}, \mathrm{IR}$, specific $\mathrm{P}$ content of algae $\left(C_{\mathrm{f}}\right)$, and $\mathrm{k}_{\mathrm{u}}$ (Table 1), and assuming a waterborne $\mathrm{PO}_{4}-\mathrm{P}$ concentration $\left(C_{\mathrm{w}}\right)$ of $10 \mu \mathrm{g} \mathrm{l^{-1 }}$, the relative importance of dietary uptake as the source of $\mathrm{P}\left(S_{\mathrm{f}}\right)$ for daphnids was calculated by the following equation:

$$
S_{\mathrm{f}}=\left(\mathrm{AE} \times \mathrm{IR} \times C_{\mathrm{f}}\right) /\left(\mathrm{k}_{\mathrm{u}} \times C_{\mathrm{w}}+\mathrm{AE} \times \mathrm{IR} \times C_{\mathrm{f}}\right)
$$

These calculations indicated that the dietary assimilation was the dominant source of $\mathrm{P}$ for daphnids at all Ca levels (>98\%), and only 1 to $2 \%$ of P was incorporated from water (Fig. 3C).

\section{Efflux and loss budget of phosphorus}

During the 3 d depuration, P was lost from Daphnia magna continuously with relatively higher rates on the second day (Fig. 4A), which was mainly due to more molts and neonates produced (Fig. 5). The pattern and rate of $\mathrm{P}$ loss were similar among the $4 \mathrm{Ca}$ levels. After $3 \mathrm{~d}$ of depuration, 36 to $45 \%$ of $\mathrm{P}$ was retained in daphnids. The efflux rate constant $\left(\mathrm{k}_{\mathrm{e}}\right)$ of $\mathrm{P}$ was calculated as the absolute value of the slope of the linear regression between the retention of $\mathrm{P}$ (natural log scale) and the depuration time (d) (Table 1). Efflux rate constant varied from 0.33 to $0.44 \mathrm{~d}^{-1} ; \mathrm{k}_{\mathrm{e}}$ was highest in the $0.5 \mathrm{mg} \mathrm{Ca}^{-1}$ treatment and became similar when the Ca concentration was higher.
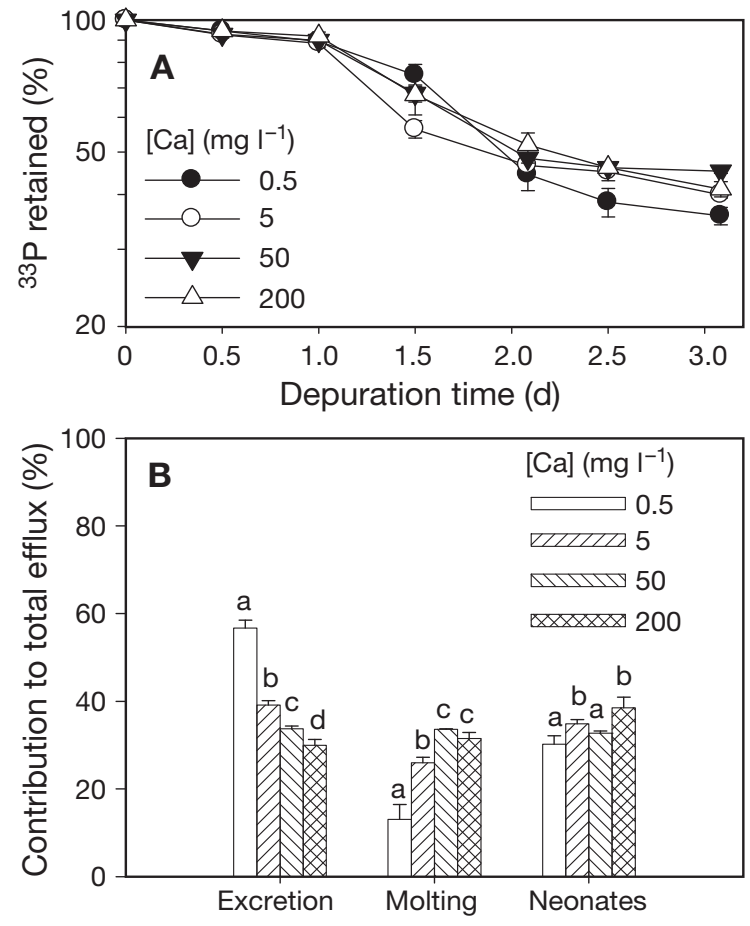

Fig. 4. Daphnia magna. (A) Percentage of ${ }^{33} \mathrm{P}$ retained in age $7 \mathrm{~d} D$. magna during $3 \mathrm{~d}$ depuration in medium with $10^{5}$ cells $\mathrm{ml}^{-1}$ of non-radioactive Chlamydomonas reinhardtti. (B) Relative contribution of excretion, molting and reproduction (neonates) to the efflux of ${ }^{33} \mathrm{P}$ from $D$. magna. Error bars: $\pm \mathrm{SD}$, $\mathrm{n}=3$. Different letters above bars denote significant differences $(p<0.05)$

Phosphorus was lost from daphnids via 3 routes: excretion, molting, and reproduction (neonates) presented in Fig. 4B. When the Ca concentration was $\geq 5 \mathrm{mg} \mathrm{l}^{-1}$, the contribution of the 3 routes was similar. In contrast, excretion was the principal route and accounted for $57 \%$ of the $\mathrm{P}$ loss in the $0.5 \mathrm{mg} \mathrm{l}^{-1}$ treatment, while the contribution of molting was only around $13 \%$. With the increase of $\mathrm{Ca}$ concentration, there was a significant increase in the relative importance of molting in the $\mathrm{P}$ loss and a decrease in the importance of excretion (Fig. 4B). The percentage of $\mathrm{P}$ allocated to reproduction was relatively stable $(\sim 35 \%)$ among all Ca levels. Phosphorus loss due to excretion reached a peak after $1.5 \mathrm{~d}\left(0.5 \mathrm{mg} \mathrm{Ca}^{-1}\right)$ or $2 \mathrm{~d}$ (other treatments) and the same pattern was observed for molting (Fig. 5), indicating that more $\mathrm{P}$ was released into water the during the molting period.

During the $3 \mathrm{~d}$ depuration, each daphnid generated $\sim 1$ molt and 4 to 5 offspring (Fig. 6A). With the elevation of Ca level, a higher portion of $\mathrm{P}$ was contained in one exuvium. Shedding 1 molt cost one daphnid 5 to $10 \%$ of the body $\mathrm{P}$ in the $0.5 \mathrm{mg} \mathrm{Ca} \mathrm{l}^{-1}$ treatment and 10 to $20 \%$ of the body $\mathrm{P}$ when the Ca level was higher (Fig. 6B). The maternal transfer of $\mathrm{P}$ to a neonate was 3 to $6 \%$ of the body $\mathrm{P}$ content at all Ca levels (Fig. 6B). 

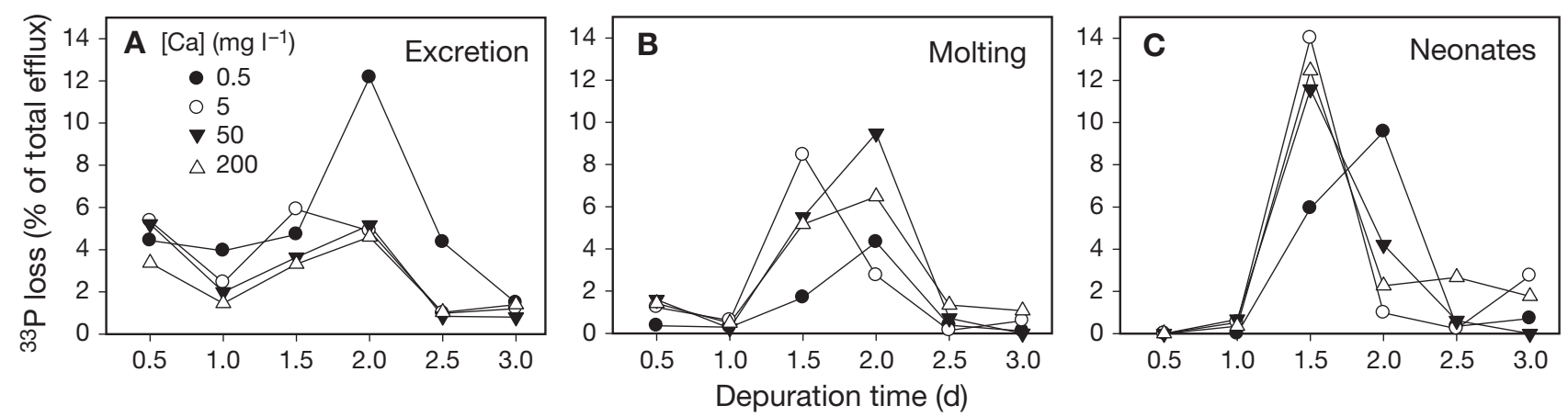

Fig. 5. Daphnia magna. ${ }^{33} \mathrm{P}$ lost from D. magna through excretion, molting and reproduction (neonates) during $3 \mathrm{~d}$ depuration at different Ca concentrations; percentages were calculated by dividing ${ }^{33} \mathrm{P}$ collected in water, molts or neonates by the ${ }^{33} \mathrm{P}$ content in the adults at the start of depuration
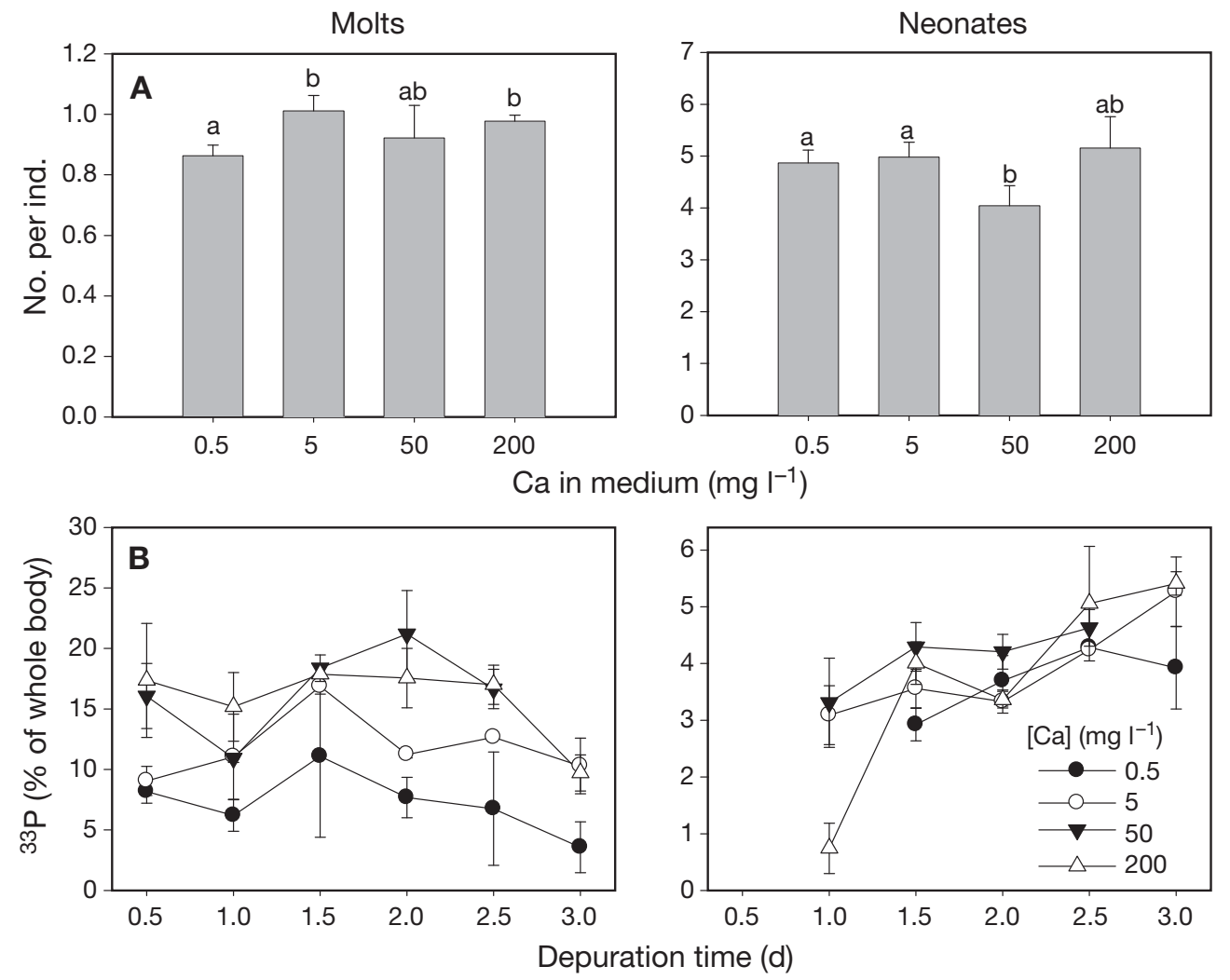

Fig. 6. Daphnia magna. (A) Number of molts and neonates produced by 1 individual during $3 \mathrm{~d}$ depuration. (B) Percentages of ${ }^{33} \mathrm{P}$ lost from 1 individual through shedding 1 molt or giving birth to 1 neonate; percentages calculated as in Fig. 5. Error bars: \pm SD, $\mathrm{n}=3$. Different letters above bars denote significant differences $(\mathrm{p}<0.05)$

\section{DISCUSSION}

The decreasing trend in $\mathrm{P}$ content of Daphnia magna with the elevation of ambient Ca concentration, and the negative relationship between the $\mathrm{P}$ and $\mathrm{Ca}$ contents were unexpected. With the increase of water Ca concentration and higher Ca content in daphnids, more calcium phosphate was expected to deposit in the exoskeleton, leading in turn to a higher $\mathrm{P}$ content of the exoskeleton and the daphnids. However, the opposite trend was observed. One possible explanation is the relatively small contribution of exoskeleton $\mathrm{P}$ to the total $\mathrm{P}$ content of daphnids. Although the exoskeleton became P-richer with the elevation of $\mathrm{Ca}$ content, this effect is overshadowed by the changes in $\mathrm{P}$ content in the somatic tissues and eggs which contain more than $80 \%$ of the total P of daphnids (Vrede et al. 1999). The major pool of $\mathrm{P}$ in Daphnia galeata is the nucleic acids, which account for 35 to $60 \%$ of the total $\mathrm{P}$ content, followed by the phospholipids which con- 
tribute 20 to $25 \%$ to the total P (Vrede et al. 1999). Therefore, the observed effects of Ca on the P content of daphnids should primarily be exerted on the nucleic acids and phospholipids. Daphnids can alleviate $\mathrm{Ca}$ limitation by reducing Ca efflux (Tan \& Wang 2009). We therefore speculate that the higher $\mathrm{P}$ content of daphnids in the lower Ca environment was due to the higher demand of nucleic acids and phospholipids involved in the active regulation of Ca efflux. Alternatively, the relative weight of exoskeleton might increase with the increase of $\mathrm{Ca}$ level due to more complete calcification, which may result in a lower $\mathrm{P}$ content in daphnids if the weight-specific $\mathrm{P}$ content in exoskeleton is lower than that in the somatic tissues. To our knowledge, there are no other data on the effects of $\mathrm{Ca}$ on $\mathrm{P}$ content of daphnids. It will be interesting to compare the $\mathrm{P}$ content of daphnids collected from lakes with different $\mathrm{Ca}$ levels but under similar food conditions.

The significantly lower P content $(0.72 \%)$ of daphnids fed P-deficient food ( $\mathrm{C}: \mathrm{P}=960)$ is consistent with many previous observations (DeMott et al. 1998, He \& Wang 2008). P content of daphnids fed with P-deficient food ( $\mathrm{C}: \mathrm{P}=940,930$, respectively) declined from 1.57 to $1.02 \%$ after $3 \mathrm{~d}$ of feeding (DeMott et al. 1998), from 1.11 to $0.65 \%$ after $5 \mathrm{~d}$ of feeding (He \& Wang 2008). Further increasing the diet quality by reducing the C:P from 93 to 79 did not increase the $\mathrm{P}$ content of daphnids, consistent with the threshold diet C:P of 138 predicted by Sterner \& Hessen (1994), above which Daphnia would experience P limitation. The increase in the P content of daphnids when they were fed higher quality food (lower C:P) was considered as evidence that the organisms were suffering a P deficit (DeMott et al. 2001). Therefore, although the daphnids cultured in a high Ca $\left(200 \mathrm{mg} \mathrm{l}^{-1}\right)$ environment had a lower P content than in a low Ca environment, these organisms should not be considered as $\mathrm{P}$ deficient because their $\mathrm{P}$ content could not be elevated by improving the food quality or increasing the food quantity. Consequently, to examine whether daphnids are suffering from $\mathrm{P}$ limitation, it is better to test whether their $\mathrm{P}$ content can be elevated by feeding them with P-sufficient food, instead of making this judgement from their low $\mathrm{P}$ content alone.

Biokinetic (or biodynamic) modeling is a useful tool to explain the variation in trace metal concentrations in aquatic organisms, with most predictions deviating less than 2-fold from the observed values (Luoma \& Rainbow 2005). The parameters of the biokinetic model were also used to study the stoichiometric regulation of phosphorus in Daphnia magna (He \& Wang 2008). A higher specific content of elements in aquatic organisms can be caused by a higher aqueous influx rate $\left(\mathrm{k}_{\mathrm{u}} \times C_{\mathrm{w}}\right)$, a higher dietary influx rate $(\mathrm{AE} \times \mathrm{IR} \times$
$\left.C_{\mathrm{f}}\right)$, a lower efflux rate $\left(\mathrm{k}_{\mathrm{e}}\right)$, a lower growth rate $(g)$ or the combination of them. Compared with trace metals, the variation in $\mathrm{P}$ content was small, indicating a strict regulation of $\mathrm{P}$ according to the environment and body conditions. Therefore, these biokinetic parameters may be regulated and variable with time, thus it will be impractical to use one single value for each biokinetic parameter to explain the approximately $40 \%$ variation in $\mathrm{P}$ content (1.05 to $1.43 \%$ ).

In our study, the AEs of P (15 to $25 \%$ ) in Daphnia magna were relatively stable over a wide range of ambient Ca concentration. Similarly, He \& Wang (2008) found that the AEs of $\mathrm{P}$ were not influenced by the $\mathrm{P}$ content of the daphnids; D. magna living on P-deficient food (molar C:P ratio $=930$ ) had lower body $\mathrm{P}$ content but AEs similar to the individuals on P-sufficient food when both groups were subsequently fed the same Psufficient food. Nevertheless, food quantity, food quality and the life stage of cladocerans can influence their AEs. For example, the P AE in adult D. magna was high $(85.4 \%)$ when food was scarce $\left(0.07 \mathrm{mg} \mathrm{C}^{-1}\right)$, and decreased exponentially with the elevation of food concentration, and leveled off (38\%) when the food concentration was above $24 \mu \mathrm{g} \mathrm{P} \mathrm{l}^{-1}\left(0.84 \mathrm{mg} \mathrm{C} \mathrm{l}^{-1}\right)(\mathrm{He}$ $\&$ Wang 2007). Ferrão-Filho et al. (2007) reported that D. pulex and Moina micrura had significantly higher AE of P from P-sufficient (molar C:P = 140) Ankistrodesmus falcatus than from $\mathrm{P}$-deficient (molar $\mathrm{C}: \mathrm{P}=$ 1000) algae, which may be due to the digestion resistance of the P-deficient algae. On the contrary, higher AEs were observed with P-deficient algae (Chlamydomonas reinhardtii) and D. magna in the studies of He \& Wang (2007, 2008). Juvenile daphnids have higher AEs of $\mathrm{P}$ than adults, possibly because they need large amounts of RNA to maintain their higher growth rate (He \& Wang 2007).

Although the weight-specific IR did not vary greatly over the large range of Ca levels, daphnids cultured in the Ca-deficient environment $\left(0.5 \mathrm{mg} \mathrm{Ca}^{-1}\right)$ had lower IR. Porter et al. (1983) reported that weight-specific filtering rates of cladocerans were negatively related to body size. In our study, IRs were lower for the Cadeficient daphnids despite their smaller sizes. He \& Wang (2008) also recorded a lower IR in P-deficient daphnids. The decrease in IR may be attributed to stress in daphnids caused by the adverse conditions (i.e. Ca or P deficiency) instead of the variation in body size.

The aqueous uptake of inorganic phosphate was trifling $(<2 \%$ contribution) when compared with the dietary source of P. Nevertheless, Urabe et al. (1997) found that the growth rate of Daphnia magna feeding on P-deficient Scenedesmus acutus (atomic C:P >1000) was significantly elevated by exposing the daphnids to water containing an extremely high concentration of inorganic $\mathrm{P}$ (124 $\mathrm{mg} \mathrm{l}^{-1}$ ) for $5 \mathrm{~h}$ per day, suggesting a 
substantial contribution of aqueous $\mathrm{P}$ when the dissolved $\mathrm{P}$ concentration is high. However, it remains possible that the uptake of inorganic $P$ in their study was not directly by the daphnids themselves, but by associated bacteria (Rigler 1961), which were then digested.

The efflux rate constant $\left(\mathrm{k}_{\mathrm{e}}\right)$ was slightly but significantly higher in the $0.5 \mathrm{mg} \mathrm{Ca}^{-1}$ treatment than the higher Ca treatments. He \& Wang (2008) also observed a higher $\mathrm{k}_{\mathrm{e}}$ in $\mathrm{P}$-sufficient than in P-deficient Daphnia magna. However, the higher $\mathrm{k}_{\mathrm{e}}$ in the $0.5 \mathrm{mg} \mathrm{Ca} \mathrm{l^{-1 }}$ treatment should not be attributed only to the higher $\mathrm{P}$ content of daphnids, because the $\mathrm{k}_{\mathrm{e}}$ were similar among the higher Ca treatments, although the P content varied. In the higher $\mathrm{Ca}$ environment, daphnids had higher $\mathrm{Ca}$ content and higher $\mathrm{k}_{\mathrm{e}}$ of $\mathrm{Ca}$ (Tan \& Wang 2009) but generally lower $\mathrm{k}_{\mathrm{e}}$ of $\mathrm{P}$, indicating that the efflux of $\mathrm{Ca}$ and $\mathrm{P}$ were decoupled. The $\mathrm{k}_{\mathrm{e}}$ of $\mathrm{P}$ was higher for adults and for daphnids fed P-sufficient food. In contrast, $\mathrm{k}_{\mathrm{e}}$ was not affected by the food quantity at $>0.07 \mathrm{mg} \mathrm{C}^{-1}$ (He \& Wang 2007).

The exuvia contained more $\mathrm{P}$ in the higher $\mathrm{Ca}$ environment, consistent with the higher contribution of molting to the efflux of $\mathrm{P}$ when Ca level was higher. Similarly, a higher proportion of Ca was lost through molting in Daphnia magna (Tan \& Wang 2009). These results indicate that $\mathrm{Ca}$ and $\mathrm{P}$ were linked in the building and shedding of molts (Hessen \& Rukke 2000). Similar numbers of molts were generated by daphnids at different Ca levels, suggesting that the molting frequencies were generally unaffected by the ambient $\mathrm{Ca}$ level, which is in agreement with Hessen et al. (2000). In their study with $D$. magna, nearly identical numbers of molts $(\sim 10)$ were collected during a $40 \mathrm{~d}$ period, regardless of Ca concentrations (0.5 to $\left.10 \mathrm{mg} \mathrm{l}^{-1}\right)$ and food concentrations ( 0.1 to $0.8 \mathrm{mg} \mathrm{Cl}^{-1}$ ).

Increasing the Ca level from 0.5 to $200 \mathrm{mg} \mathrm{l}^{-1}$ resulted in a lower proportion of P lost through excretion (57 to $30 \%$ ) and a higher proportion lost through molting (13 to $32 \%)$, whereas the percentages of P transferred to offspring were relatively constant (30 to $39 \%)$. Therefore, it appears that, in high-Ca waters, less $\mathrm{P}$ was immediately returned by daphnids into ambient water, and more $\mathrm{P}$ was lost into the sediment with the sinking of molts, thereby reducing the availability of $\mathrm{P}$ to primary producers. However, in a mesocosm study, $\mathrm{P}$ sequestered from phytoplankton was mainly converted to Daphnia spp. biomass and not lost by the sedimentation of molts (Sommer et al. 2003). The duration of their study $(\sim 17 \mathrm{~d})$ was relatively short, compared to the life span of daphnids (usually $>30 \mathrm{~d}$ ). Sedimentation of molts may become more important if the experiment runs for a longer duration. Field observations indicate that Daphnia spp. tissues play an important role in the sedimentation of $\mathrm{P}$ in lakes (Sar- nelle 1992). It should be noted that the effects of ambient $\mathrm{Ca}$ on the relative importance of different routes of $\mathrm{P}$ loss may be affected by the P content of the diets.

The simultaneous fluctuation in the contribution of excretion and molting to the efflux of $\mathrm{P}$ indicates that the release of $\mathrm{P}$ into the dissolved phase was substantially higher during the molting process. Consistently, Scavia \& McFarland (1982) found that the rate of $\mathrm{P}$ release by Daphnia magna was elevated 6.7-fold at and after ecdysis, which was presumably due to the higher permeability of the new exoskeleton. The release of $\mathrm{P}$ contained in the molting fluid was another possible explanation (Peters \& Rigler 1973). A higher release rate during molting was also observed for Ca (Tan \& Wang 2009), again suggesting the association of $\mathrm{P}$ and $\mathrm{Ca}$ in the molting process.

To conclude, Daphnia magna living in a higher $\mathrm{Ca}$ environment had a lower specific $\mathrm{P}$ content, and there was a negative relationship between $\mathrm{P}$ and $\mathrm{Ca}$ contents. Therefore, Ca concentration should be considered when comparing the $\mathrm{P}$ content of daphnids collected from different localities. As the source of $\mathrm{P}$ for daphnids, incorporating inorganic P from water is negligible when compared with the assimilation of $\mathrm{P}$ from food. In high Ca waters, daphnids returned more $\mathrm{P}$ to the sediment by molting P-rich exuvia, and returned less $\mathrm{P}$ to ambient water through excretion, which may lead to less $\mathrm{P}$ availability for primary producers.

Acknowledgements: We thank 3 anonymous reviewers for their comments on this study.

\section{LITERATURE CITED}

Alstad NEW, Skardal L, Hessen DO (1999) The effect of calcium concentration on the calcification of Daphnia magna. Limnol Oceanogr 44:2011-2017

Andersen T, Hessen DO (1991) Carbon, nitrogen, and phosphorus content of freshwater zooplankton. Limnol Oceanogr 36:807-814

Andersson G, Granéli W, Stenson J (1988) The influence of animals on phosphorus cycling in lake ecosystems. Hydrobiologia 170:267-284

DeMott WR, Gulati RD, Siewertsen K (1998) Effects of phosphorus-deficient diets on the carbon and phosphorus balance of Daphnia magna. Limnol Oceanogr 43:1147-1161

DeMott WR, Gulati RD, Van Donk E (2001) Effects of dietary phosphorus deficiency on the abundance, phosphorus balance, and growth of Daphnia cucullata in three hypereutrophic Dutch lakes. Limnol Oceanogr 46:1871-1880

DeMott WR, Pape BJ, Tessier AJ (2004) Patterns and sources of variation in Daphnia phosphorus content in nature. Aquat Ecol 38:433-440

Ferrão-Filho AS, Tessier AJ, DeMott WR (2007) Sensitivity of herbivorous zooplankton to phosphorus-deficient diets: testing stoichiometric theory and the growth rate hypothesis. Limnol Oceanogr 52:407-415

Fryer G (1985) The ecology and distribution of the genus Daphnia (Crustacea: Cladocera) in restricted areas: the 
pattern in Yorkshire. J Nat Hist 19:97-128

Guan R, Wang WX (2006) Multiphase biokinetic modeling of cadmium accumulation in Daphnia magna from dietary and aqueous sources. Environ Toxicol Chem 25:2840-2846

Guillard RRL, Lorenzen CJ (1972) Yellow-green algae with chlorophyllide C. J Phycol 8:10-14

He X, Wang WX (2007) Kinetics of phosphorus in Daphnia at different food concentrations and carbon:phosphorus ratios. Limnol Oceanogr 52:395-406

He X, Wang WX (2008) Stoichiometric regulation of carbon and phosphorus in P-deficient Daphnia magna. Limnol Oceanogr 53:244-254

Hessen DO (1990) Carbon, nitrogen and phosphorus status in Daphnia at varying food conditions. J Plankton Res 12: 1239-1249

> Hessen DO, Alstad NEW, Liz S (2000) Calcium limitation in Daphnia magna. J Plankton Res 22:553-568

Hessen DO, Lyche A (1991) Inter- and intraspecific variations in zooplankton element composition. Arch Hydrobiol 121: 343-353

Hessen DO, Rukke NA (2000) The costs of moulting in Daphnia; mineral regulation of carbon budgets. Freshw Biol 45:169-178

Hooper HL, Connon R, Callaghan A, Fryer G and others (2008) The ecological niche of Daphnia magna characterized using population growth rate. Ecology 89: 1015-1022

Jeziorski A, Yan ND (2006) Species identity and aqueous calcium concentrations as determinants of calcium concentrations of freshwater crustacean zooplankton. Can J Fish Aquat Sci 63:1007-1013

Kawasaki T, Yoshimura H, Shibue T, Ikeuchi Y and others (2004) Crystalline calcium phosphate and magnetic mineral content of Daphnia resting eggs. Zoolog Sci 21:63-67

Luoma SN, Rainbow PS (2005) Why is metal bioaccumulation so variable? Biodynamics as a unifying concept. Environ Sci Technol 39:1921-1931

Peters RH, Rigler FH (1973) Phosphorus release by Daphnia. Limnol Oceanogr 18:821-839

Porter KG, Feig YS, Vetter EF (1983) Morphology, flow regimes, and filtering rates of Daphnia, Ceriodaphnia, and Bosmina fed natural bacteria. Oecologia 58:156-163

Rigler FH (1961) The uptake and release of inorganic phosphorus by Daphnia magna Straus. Limnol Oceanogr 6:

Editorial responsibility: Hans Heinrich Janssen,

Oldendorf/Luhe, Germany
$165-174$

Samel A, Ziegenfuss M, Goulden CE, Banks S, Baer KN (1999) Culturing and bioassay testing of Daphnia magna using Elendt M4, Elendt M7, and COMBO media. Ecotoxicol Environ Saf 43:103-110

Sarnelle O (1992) Contrasting effects of Daphnia on ratios of nitrogen to phosphorus in a eutrophic, hard-water lake. Limnol Oceanogr 37:1527-1542

Scavia D, McFarland MJ (1982) Phosphorus release patterns and the effects of reproductive stage and ecdysis in Daphnia magna. Can J Fish Aquat Sci 39:1310-1314

Solorzano L, Sharp J (1980) Determination of total dissolved phosphorus and particulate phosphorus in natural waters. Limnol Oceanogr 25:754-758

Sommer F, Santer B, Jamieson C, Hansen T, Sommer U (2003) Daphnia population growth but not moulting is a substantial phosphorus drain for phytoplankton. Freshw Biol 48:67-74

Sterner RW, Hessen DO (1994) Algal nutrient limitation and the nutrition of aquatic herbivores. Annu Rev Ecol Syst 25: $1-29$

Sterner RW, Hagemeier DD, Smith WL, Smith RF (1993) Phytoplankton nutrient limitation and food quality for Daphnia. Limnol Oceanogr 38:857-871

Tan QG, Wang WX (2008) The influences of ambient and body calcium on cadmium and zinc accumulation in Daphnia magna. Environ Toxicol Chem 27:1605-1613

Tan QG, Wang WX (2009) The regulation of Ca in Daphnia magna reared in different $\mathrm{Ca}$ environments. Limnol Oceanogr (in press)

Urabe J, Clasen J, Sterner RW (1997) Phosphorus limitation of Daphnia growth: Is it real? Limnol Oceanogr 42: 1436-1443

Vrede T, Andersen T, Hessen DO (1999) Phosphorus distribution in three crustacean zooplankton species. Limnol Oceanogr 44:225-229

Wærvågen SB, Rukke NA, Hessen DO (2002) Calcium content of crustacean zooplankton and its potential role in species distribution. Freshw Biol 47:1866-1878

Wang WX, Fisher NS, Luoma SN (1996) Kinetic determinations of trace element bioaccumulation in the mussel Mytilus edulis. Mar Ecol Prog Ser 140:91-113

Yu RQ, Wang WX (2002) Trace metal assimilation and release budget in Daphnia magna. Limnol Oceanogr 47:495-504

Submitted: October 14, 2008; Accepted: January 13, 2009

Proofs received from author(s): January 29, 2009 